\title{
Determinants of Islamic Social Responsibility Disclosure the Case of Islamic Banks: Cross Country Analysis
}

\author{
Agus Maulana1, Evony Silvino Violita ${ }^{2 *}$ \\ ${ }^{1}$ Department of Accounting, Universitas Pembangunan Nasional Veteran \\ Jakarta, Jakarta, Indonesia \\ ${ }^{2}$ Department of Accounting, Universitas Indonesia, Depok, Indonesia \\ *evony.silvino@gmail.com
}

Article History

\begin{tabular}{lll}
\hline Received & $:$ & $2020-04-25$ \\
\hline Revised & $:$ & $2020-12-03$ \\
\hline Accepted & $:$ & $2020-12-08$ \\
\hline
\end{tabular}

\section{Abstract}

Introduction to The Problem: The rapid growth of Islamic financial institutions around the world attracts a lot of attention, but its growth is not supported by adequate accountability. Several evidence show that accountability of Islamic banks is still very low. The lack of accountability may cause low public trust, so it is important to study the determinant of Islamic Social Responsibility Disclosure by Islamic Bank.

Purpose/Objective Study: This study intends to examine the determinants of Islamic Social Responsibility disclosure (ISR). So, practitioners and academics can get a clear view of Islamic Bank's accountability through ISR disclosure.

Design/Methodology/Approach: This paper applies some theories such as stakeholder theories, agency theory, and legitimacy theory to developed hypotheses linking ISR disclosure and its determinants (internationality, Islamic Corporate Governance, and Socio-Political Context). This paper uses the content analysis method to assess the ISR disclosure of Islamic banks from 13 countries spanning from 2014 to 2016 . The ISR index consists of 72 items developed based on AAOIFI. Finally, OLS Regression Analysis is used to test the hypotheses.

Findings: The paper finds that the level of ISR disclosure is still very low $(44 \%)$. From the internationality aspect, we found that the proportion of foreign ownership and the status of the multinational corporation influenced the level of ISR disclosure, but we did not find evidence that the CEO's overseas experience affected the level of disclosure. This paper also confirms that Islamic Corporate Governance and Socio-Political context are the main determinant of ISR disclosure by Islamic Bank.

Ihtifaz: Journal of Islamic Economics, Finance, and Banking

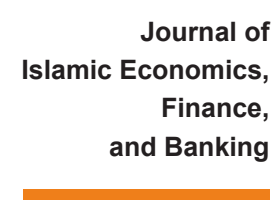

Vol. 4, No. 1, June 2021, pp. 59-79, ISSN p:2622-4755 e:2622-4798

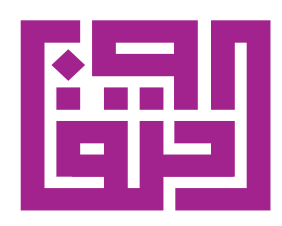

IHTIFAZ

UNIVERSITAS AHMAD DAHLAN

Kampus 4 Universitas Ahmad Dahlan Jl. Ringroad Selatan, Tamanan Yanguntapan, Bantul Yogyakarta 55191 
Paper Type: Empirical Research Article

Keywords: Islamic Social Responsibility; Islamic Corporate Governance; PRCL; IHTIFAZ - JIEFB sharia disclosure index; social disclosure index.

\section{INTRODUCTION}

The rapid growth of Islamic financial institutions around the world attracts a lot of attention, but it is not supported by adequate accountability. Ernst and Young (2016) reported that assets participation of Islamic banks on international assets reached US \$ 882 Billion, growing $16 \%$ over the last 4 years. There were 150 Islamic banks around the world in 2016, with growth rates 50 percent faster than the overall banking sector (Sellami \& Tahari, 2017). Contrary, several empirical studies found that accountability of Islamic banks is still very weak (El-Halaby \& Hussainey, 2015; Farook et al., 2011) and lack of transparency (Srairi, 2019). Therefore, accountability of Islamic banks is still questionable.

Islamic Bank has unique characteristics compared with other financial institutions. Islamic banking business model is principally based on Islamic sharia values, ethics and social responsibility (Muneeza et al., 2020). Therefore, every person in the company is vertically responsible to God and also horizontally to fellow human beings, especially all stakeholders of the company (Haniffa \& Cooke, 2002). Related to the responsibility to the human beings, Islamic banks need to maintain their communication with stakeholders and disclose sufficient information about the shariah compliance of the company's business processes and corporate social activities to get the support and trust from its stakeholders (El-Halaby \& Hussainey, 2016).

Based on Al-Qur'an, the obligation of Islamic bank management as the manager of the company to disclose the correct information mentioned in the letter of Al-Baqarah verse 42 which means "And do not mix the truth and falsehood. And do not hide the truth, but you know" (The Qur'an, 2:42). Therefore, Islamic banks face reputational risks if they fail to maintain shariah compliance communication of its business processes and social responsibility activities.

This study aims to examine the factors that can affect the level of Islamic Social Responsibility (ISR) disclosure of Islamic Bank. ISR Disclosure in this study refers to disclosure of shariah compliance and corporate social responsibility. The disclosure of shariah compliance relates to (1) how the company discloses that its products are in accordance with sharia principles, (2) how the company ensures and controls profit sharing according to sharia principles and regulations, (3) how the company handles non-shariah compliant income (haram). In addition, the corporate social responsibility disclosure refers to disclosure of a company's accountability to its stakeholders such as customers, employee, regulator or government, etc. Factor determinants tested in 
this study are internationality of Islamic bank, socio-political context, and Islamic corporate governance.

Prior research concerning bank disclosure has been conducted by several researchers within the scope of one country or regions (Table 1). Vinnicombe (2010) measured the level of disclosure of Islamic banks in Bahrain based on AAOIFI standard in 2004-2007 using an index consisting of four main dimensions. This research is a preliminary research, so the index used in this study was very simple. Furthermore, Farook et al. (2011) examines the determinants of CSR disclosure of Islamic banks using disclosure items following Maali, Casson, \& Napier (2006) which consists of 32 items so that the index used is still not comprehensive.

El-Halaby \& Hussainey (2016) study examined the determinants of disclosure level in the East and North Africa region (MENA) based on AAOIFI disclosure indexes, Governance Standard 1 (GS 1), Governance Standard 7 (GS 7), and Financial Accounting Standard 1 (FAS 1). This study has advantages in the completeness and reliability of the index used. Furthermore, similar to El-Halaby \& Hussainey (2016), Sellami \& Tahari (2017) contribute to enhance the research design with separation of the voluntary and mandatory AAOIFI countries, however the scope of study is limited.

There are several limitations and weaknesses of previous research studies that need to be improved in this advanced research. The first is from the scope of the study, so far there is little research using crosscountry data, and most cross-country research is limited to a single region such as MENA, GCC, and so on. This limitation resulted in a weakness in terms of generalization. The second is determinant factors used. Previous studies relatively have identical determinants such as SSB, corporate characteristics, and culture. With fast growth of Islamic banks, we consider there are new factors that affect the level of disclosure of ISR.

This study intends to fill the previous research gap with some contribution. First, we expand the research scope. We use Islamic bank data in countries with the highest market share according to Ernst and Young (2016) covering QISMUT (Qatar, Indonesia, Saudi Arabia, Malaysia, UAE and Turkey), the GCC region (Bahrain, Kuwait and Oman), South Asia Region (Pakistan and Bangladesh), and other countries such as Egypt and Jordan. Totally, we employed Islamic bank data from 13 countries. Secondly, this study contributes to the addition of new untested factors that are the internationality of Islamic banks. Along with the rapid development of Islamic banks across national borders, experts who are beginning to engage in the development of more experienced international standards, and practitioners who come from other countries or have experience learning from other countries become an important issue to explain how an Islamic bank can increase the level of ISR disclosure of Islamic banks. 


\section{LITERATURE REVIEW}

IHTIFAZ - JIEFB

\section{Islamic Bank and Disclosure}

Based on the major literature, there are four theories that can explain why Islamic Bank discloses ISR which is Stakeholder Theory, Legitimacy Theory, Agency Theory, and Signaling Theory (Clarkson, 1995; Fama \& Jensen, 1983; Hahn \& Kühnen, 2013). According to legitimacy theory, the company needs to disclose that its activities are not problematic in order to get the support and approval from the community. ISR disclosure is a company tool to legitimize a company's activities in accordance with prevailing norms (Deegan, 2002).

From the side of stakeholder theory, the company faces various stakeholders that are influenced or influenced by the company's activities. Successful in meeting stakeholder expectations is critical to Islamic Bank, and disclosure of ISR in annual reports is one of the companies effort to get support from various stakeholders (Clarkson, 1995). In addition, agency theory stated that agency costs arise from information asymmetry and conflict of interest between management as managers and shareholders as the owner (Fama \& Jensen, 1983). ISR disclosure plays a role in reducing the information asymmetry. Based on signaling theory, the disclosure of ISR is a form of message from the manager to the owner to signal about the performance of the company's (Hahn \& Kühnen, 2013).

\section{Islamic Social Responsibility Disclosure}

Islamic social responsibility or Islamic social reporting is an extension concept of corporate social responsibility (CSR). The CSR concept emerges from the view that the company is not only responsible for generating profit for shareholders (Nahar et al., 2020), but also responsible to all stakeholders (Freeman, 1994). CSR covers the company in general and focuses on corporate responsibility in the triple bottom line of economy, social, and environment. While the ISR includes Islamic business entities and focuses on corporate responsibility viewed from economic, social, and spiritual aspects (Haniffa \& Cooke, 2002; Khurshid et al., 2014; Riduwan et al., 2020).

Table 1. Summary of Prior Research

\begin{tabular}{|c|c|c|c|}
\hline $\begin{array}{l}\text { Author } \\
\text { (Year) }\end{array}$ & $\begin{array}{l}\text { Dependent } \\
\text { Variables }\end{array}$ & $\begin{array}{c}\text { Independent } \\
\text { Variables }\end{array}$ & Results \\
\hline $\begin{array}{l}\text { Farook et al. } \\
\text { (2011) }\end{array}$ & $\begin{array}{l}\text { The CSR index } \\
\text { consists of } 32 \\
\text { items based on } \\
\text { the research } \\
\text { of Maali et al. } \\
(2003)\end{array}$ & $\begin{array}{l}\text { - Political Right and } \\
\text { Civil Liberties } \\
\text { - Proportion of } \\
\text { Muslim Population } \\
\text { - ICG-Score } \\
\text { - Investment } \\
\text { - Account Holders } \\
\text { - Company Size }\end{array}$ & $\begin{array}{l}\text { - The disclosure of } \\
\text { Islamic bank CSR } \\
\text { is significantly } \\
\text { determined by the } \\
\text { public relevance, } \\
\text { the sharia CG } \\
\text { mechanism, total } \\
\text { investment assets, } \\
\text { and socio-political } \\
\text { context }\end{array}$ \\
\hline
\end{tabular}




\begin{tabular}{|c|c|c|c|c|}
\hline $\begin{array}{l}\text { Vinnicombe } \\
\text { (2010) }\end{array}$ & $\begin{array}{l}\text { Disclosure } \\
\text { compliance } \\
\text { index based } \\
\text { on AAOIFI } \\
\text { - Sharia } \\
\text { Supervisory } \\
\text { Board } \\
\text { - Mudaraba } \\
\text { financing } \\
\text { - Murabaha } \\
\text { financing } \\
\text { - Zakah }\end{array}$ & $\begin{array}{l}\text { - no independent } \\
\text { variable }\end{array}$ & $\begin{array}{l}\text { - The highest level of } \\
\text { disclosure is related } \\
\text { to the governance } \\
\text { disclosure } \\
\text { standard that } \\
\text { disclosure SSB and } \\
\text { murabaha contract } \\
\text { information. } \\
\text { - The lowest level } \\
\text { of disclosure is } \\
\text { related to zakah } \\
\text { and mudarabah } \\
\text { contract. }\end{array}$ & 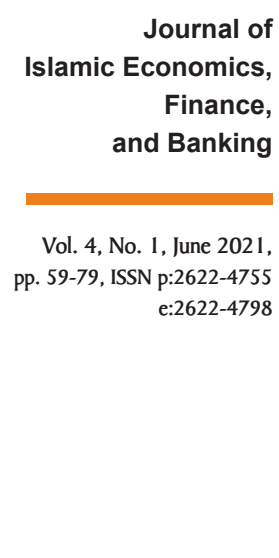 \\
\hline $\begin{array}{l}\text { El-Halaby } \\
\text { and } \\
\text { Hussainey } \\
\text { (2016) }\end{array}$ & $\begin{array}{l}\text { Index } \\
\text { Disclosure } \\
\text { based on } \\
\text { AAOIFI (GS 1, } \\
\text { GS 7, and FAS } \\
\text { 1) } \\
\text { - Sharia } \\
\text { disclosure } \\
\text { index } \\
\text { - Social } \\
\text { disclosure } \\
\text { index } \\
\text { - Financial } \\
\text { disclosure } \\
\text { index }\end{array}$ & $\begin{array}{l}\text { Firm } \\
\text { Characteristics } \\
\text { - Auditor } \\
\text { - Age } \\
\text { - Size } \\
\text { - Profitability } \\
\text { - Shariah audit } \\
\text { department } \\
\text { BoD } \\
\text { Characteristics } \\
\text { - Block holder } \\
\text { - Ownership } \\
\text { - Duality } \\
\text { - Board } \\
\text { Independence } \\
\text { sSB } \\
\text { characteristics } \\
\text {-SSB size } \\
\text {-Dual membership } \\
\text { - Reputation } \\
\text { Culture } \\
\text { Uncertainty } \\
\text { avoidance }\end{array}$ & $\begin{array}{l}\text { - Size, presence } \\
\text { of shariah audit } \\
\text { department, age, } \\
\text { CG and SSB is a } \\
\text { major determinant } \\
\text { of disclosure } \\
\text { compliance with } \\
\text { AAOIFI standards. }\end{array}$ & \\
\hline $\begin{array}{l}\text { Sellami } \\
\text { and Tahari } \\
\text { (2017) }\end{array}$ & $\begin{array}{l}\text { - Disclosure } \\
\text { indexes are } \\
\text { based on } \\
\text { IFRS 7, FAS } \\
1 \text {, and FAS } 5\end{array}$ & $\begin{array}{l}\text { - Size } \\
\text { - Auditor Type } \\
\text { - Listing Status } \\
\text { - Audit Committee } \\
\text { - Age } \\
\text { - Domicile }\end{array}$ & $\begin{array}{l}\text { - The level of } \\
\text { disclosure between } \\
\text { banks varies widely. } \\
\text { The dominant } \\
\text { influential factor } \\
\text { is the status of } \\
\text { the listing, the } \\
\text { existence of an } \\
\text { audit committee, } \\
\text { the age of the } \\
\text { bank, and the } \\
\text { bank's domicile } \\
\text { country. }\end{array}$ & \\
\hline
\end{tabular}

Ihtifaz: Journal of Islamic Economics, Finance, and Banking 
According to Haniffa (2001), the disclosure of social responsibility in a conventional system, which includes only material and moral aspects, IHTIFAZ - JIEFB does not adequately accommodate Islamic business entities that have different characteristics. Stakeholders of Islamic business entities, especially a Muslim is faced with a decision based on Islamic law that considers the existence of halal and haram. Therefore, the reporting of corporate social responsibility must also pay attention to the spiritual aspect.

\section{Internationality of Islamic Bank}

The rapid development of the Islamic finance industry in the last two decades has allowed Islamic banks to grow beyond national borders. Several banks such as Alrajhi Bank of Saudi Arabia, Albaraka from Bahrain, Kuwait Finance House from Kuwait and Bank Muamalat from Indonesia expanded by opening branch offices in several other countries (IFSB, 2016). In addition to expansion in its business processes, in the case of Islamic banking governance also began to develop with the involvement of experts who work together in international institutions such as AAOIFI, Islamic Financial Service Board, and other cooperation activities such as international conferences and seminars. The existence of connectivity of experts and practitioners in the field of Islamic finance is expected to encourage more advanced Islamic banking governance and improve the accountability of Islamic banks.

Several studies related to the internationality of the company show that internationality relates to the level of CSR disclosure and social performance of the company (Branco \& Rodrigues, 2008; Slater et al., 2009). Slater et al. (2009) also found that the CEO's experience working abroad affects the social performance of the company, and is moderated strongly by its functional background in the company. The following are the factors that are the determinants of ISR disclosure of its internationalization aspect.

\section{Foreign Ownership}

Looking at the growth prospects of Islamic banks, the increasing opening of inter-state investment, and the abundance of international cooperation make Islamic bank ownership spread across borders where Islamic banks are derived. In terms of stakeholder theory, companies that are partly owned by foreigners will be more broadly disclosed in the company's information as the company tries to meet the increasingly widespread and differentiated shareholders' expectations (Freeman et al., 2004). Based on this foundation, the hypothesis of this study is,

H1a: The proportion of foreign ownership is positively associated with the level of ISR disclosure 


\section{CEO's overseas experience}

The CEO of a company has a central role in determining company policies. The CEO has the authority to use the company's resources to disclose information in the company's annual report. Slater et al. (2009) found that the presence of CEOs who have experience working overseas relate to the level of corporate social responsibility disclosure. Based on this foundation, the hypothesis of this study is,

H1b: The CEO's overseas experience is positively associated with the level of ISR disclosure

\section{Multinational Islamic Bank}

The development of Islamic finance industry around the world has made some Islamic banks expand by opening subsidiaries or banks affiliated with banks in other countries such as Alrajhi Bank from Saudi Arabia, Albaraka from Bahrain, Kuwait Finance House from Kuwait, and Bank Muamalat from Indonesia (IFSB, 2016). Several previous studies have examined how international trade influences disclosure rates (Branco \& Rodrigues, 2008; Choi, 1999). In terms of stakeholder theory, the broader the scope of the company's operations the wider the stakeholder influencing and influenced by the company, therefore the company has a large incentive to disclose more information in order to meet the expectations of its stakeholders (Freeman et al., 2004). In addition, internationally affiliated banks will have a large incentive to maintain communication with stakeholders because neither the good name of the bank in one country will affect the bank's overall reputation internationally. Based on this foundation, the hypothesis of this study is:

H1: The status of a multinational Islamic Bank is positively associated with the level of ISR disclosure

\section{Islamic Corporate Governance of Shariah Supervisory Board}

In conducting its business activities, Islamic banks have differences with other conventional banks because their business activities are based on Islamic Law (sharia). Sharia principles cause Islamic banks put more emphasis on moral values than other ratings (Hamdi \& Zarai, 2012; Wibowo, 2020). Sharia principles make the Islamic banking governance different from that of conventional banks, seen from dual governance of Islamic banks (Anglo-American and the Islamic legal system) (Mersni \& Ben Othman, 2016). The evidence of dual governance system is that there are two fundamental bodies which is the Board of Directors and the Shariah Supervisory Board (SSB)

SSB is an independent body within an Islamic bank whose actions are not influenced by management, board of directors or shareholders. The function of SSB is to ensure that Islamic banks are compliant with Islamic law to meet the ethical expectations of bank customers

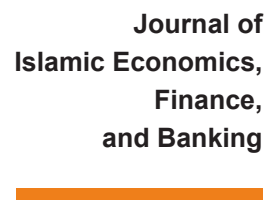

Vol. 4, No. 1, June 2021, pp. 59-79, ISSN p:2622-4755 e:2622-4798 
(Abu-Tapanjeh, 2009). SSB acts as an internal control body within the organization tasked with reviewing and supervising bank activities and IHTIFAZ - JIEFB policies to ensure the conformity of bank transactions with Islamic law (Garas \& Pierce, 2010). Farook et al. (2011) found that the presence of SSB and its characteristics affected the level of disclosure in Islamic banks. (Akhtaruddin et al., 2009) shows that the number of SSB in Islamic banks can affect the level of disclosure. The Agency Theory predicts that the more councils that have expertise in certain fields the more effective the monitoring function of the board (Singh et al., 2004).

In addition to the large number of SSB, several studies have found that the presence of SSB members acting as SSB in some banks (cross membership) affects the level of disclosure (Farook et al., 2011). The existence of SSB that has a cross-membership role is considered to increase the transparency of information through the comparison of knowledge obtained from other companies (Dahya et al., 1996). In addition, other characteristics of SSB that may affect disclosure levels are the educational background and reputation of SSB members. Farook et al. (2011) found that the reputation of SSB incorporated in AAOIFI committee members influenced the disclosure rate of Islamic banks. Based on the foundation and the results of previous research, the hypothesis of this study is,

H2: The score of Islamic Corporate Governance is positively associated with the level of ISR disclosure

\section{Socio-Political Context}

Islamic Bank is an entity whose activities are also determined based on the pattern of interaction in the environment where it operates. Several studies have found that not only internal factors and firm characteristics alone can determine the degree of disclosure of a company, but also there are contextual or environmental factors that affect disclosure levels (Fifka \& Pobizhan, 2014; Mitchell Williams, 1999).

Islamic banks currently operate in wide social and political environments and each country has different economic political characteristics, so that the flow of information and dialogue between banks and the environment is influenced by the mutual relationship between the rights and obligations of all parties in the environment (Farook et al., 2011). Mitchell Williams (1999) tries to empirically examine inter-country variables that may explain the variation in corporate social and environmental disclosure levels in its annual report. The results of his study found that variations in disclosure rates were significantly determined by culture (uncertainty avoidance and masculinity) and political and civil systems.

One of the contextual factors that can affect the interaction of mutual relationships between rights and obligations within a country is Political Right and Civil Liberties (PRCL) (Freedom House / Expanding 
Freedom and Democracy, n.d.). Each country has a different pattern in implementing political rights and civil liberties. There are countries that provide widespread political and civil liberties (freedom), but there are also countries that further restrain their political activities and civil liberties (repression). According to (Thompson \& Gastil, 1982) the higher the political and civil repressive (repressive) levels, the effectiveness and influence of the social interest agencies will decline. In a country

Journal of Islamic Economics, Finance, and Banking

Vol. 4, No. 1, June 2021, pp. 59-79, ISSN p:2622-4755 e:2622-4798 where the system and its political freedoms are repressive, the interest groups of both Islamic and other groups have no ability to voice their concerns about organizational behavior. Therefore, under a repressive social and political environment, an organization may face lower social pressure (Mitchell Williams, 1999).

Therefore, an Islamic bank operating in a relatively open society with a high degree of freedom will provide justification for legitimizing its existence so as to disclose higher ISR information. Based on the foundation, the hypothesis of this study is,

H3: The more freedom the socio-political conditions of a country, the higher the level of ISR disclosure of Islamic banks in the country.

\section{METHODOLOGY}

\section{Data and Sample}

The object of this research is all Islamic banks located in countries that belong to countries that have the largest market share according to Ernst and Young (2016) This study therefore involves Islamic banks from 13 countries comprising Qatar, Indonesia, Saudi Arabia, Malaysia, UAE and Turkey, Bahrain, Kuwait, Oman, Pakistan, Bangladesh, Egypt and Jordan. The sample in this research is chosen by purposive sampling technique. The sample criteria used are (1) Islamic Banks that publish a complete annual report in 2014-2016 available and publicly accessible; (2) Annual reports are published in Indonesian or English; (3) Financial data and biography of the council the company's sharia supervisor is available. Financial data and information disclosure of ISR is obtained from the annual report issued by the company, while additional data related to the reputation and qualification of shariah supervisory board are obtained from the Islamic banker database.

\section{Development of AAOIFI-Based ISR Index}

This index of disclosure in the study can be interpreted as a list of items and dimensions that serve as a benchmark on what Islamic banks should disclose in their annual report. Several previous studies each have different indexes that serve as the basis for disclosure. Vinnicombe (2010) developed an indexing index based on AAOIFI consisting of four main dimensions: (1) Sharia Supervisory Board, (2) Mudaraba financing, (3) Murabaha financing, and (4) Zakah. Sellami \& Tahari (2017) developed disclosure indexes based on IFRS 7 and AAOIFI (FAS 
1 and FAS 5). While El-Halaby \& Hussainey (2016) use AAOIFI's special disclosure index based on GS 1, GS 7, and FAS 1.

IHTIFAZ - JIEFB

This study uses the ISR disclosure index based on AAOIFI as set forth in GS 1 and GS 7 (AAOIFI, 2015b, 2015a). As for determining the disclosure items for each ISR dimension, the researcher follows El-Halaby \& Hussainey (2016). Overall, the ISR index in this study is divided into 2 parts, namely sharia disclosure index and social disclosure index with a total of 72 items.

Table 2. Number of Item Disclosure

\begin{tabular}{cccc}
\hline $\begin{array}{c}\text { AAOIFI } \\
\text { Standard }\end{array}$ & Type of Index & $\begin{array}{c}\text { Number } \\
\text { of Items }\end{array}$ & Percentage \\
\hline GS No. 1 & Sharia Disclosure Index & 14 & $19.44 \%$ \\
GS No. 7 & Social Disclosure Index & 58 & $80.55 \%$ \\
Total Item & & 72 & $100 \%$ \\
\hline
\end{tabular}

From Table 2 we can see that there are two types of indexes: the syariah disclosure index taken from AAOIFI GS 1, consists of 14 items that reveal the compliance of Islamic banks to sharia principles. The second is the social disclosure index taken from AAOIFI GS 7, consists of 58 items that reveal the social responsibility (CSR) activity of Islamic banks.

\section{Variable Measurement and Model Specification}

The dependent variable in this study is the level of ISR disclosure based on AAOIFI i.e., Governance Standards No. 1 (GS 1) and Governance Standards No.7 (GS 7). Based on these standards, the disclosure of ISR in this study is divided into two categories of indexes namely the index of Syariah disclosure and social disclosure index.

To determine these ISR disclosure items, researchers follow the ways used by El-Halaby \& Hussainey (2016). First, we look at the main components or key dimensions of ISR disclosure presented in Appendix (E) Example of Disclosure and Presentation Formats (AAOIFI, 2015a). After obtaining the main dimensions of ISR disclosure, the researcher then refers each item related to that dimension to the disclosure standard specified by AAOIFI. For some common items such as disclosure related to company policy, the researcher adds disclosure items from the details contained in the ISR implementation standards set forth in GS 7.

To measure the level of disclosure used method of content analysis with ordinal coding method that is value 0 if not disclosed and 1 if disclosed (Guthrie \& Parker, 1989). The overall score is calculated based on the following formula:

$$
D I C S_{i t}=\frac{\sum_{t=1}^{n} X_{i j t}}{N}
$$


Level of disclosure of Islamic bank $I$ in year $t$, is determined by the disclosure item each $X i j t$ that is disclosure item $X$, on islamic bank $i$, on dimension $j$ and at time $t$. For details of items on this disclosure index can be seen in the attachment that has the final section. Table 3 illustrates the overall measurement of variables in this study.

Table 3. Variable Measurement

\begin{tabular}{lll}
\hline \multicolumn{1}{c}{ Variables } & Symbol & \multicolumn{1}{c}{ Measurement } \\
\hline Dependent Variables & & \\
\hline $\begin{array}{l}\text { Islamic Social } \\
\begin{array}{l}\text { Responsibility } \\
\text { Disclosure }\end{array}\end{array}$ & DISC & $\begin{array}{l}\text { Content analysis using disclosure } \\
\text { index based on AAOIFI (GS 1 and } \\
\text { GS7). }\end{array}$ \\
\hline
\end{tabular}

Independent Variables

\begin{tabular}{|c|c|c|}
\hline \multicolumn{3}{|l|}{ Internationalization } \\
\hline $\begin{array}{l}\text { - Foreign Ownership } \\
\text { - CEO's Overseas } \\
\text { Experience }\end{array}$ & $\begin{array}{l}\text { FOREIGN } \\
\text { EXP } \\
\text { MULTI }\end{array}$ & $\begin{array}{l}\text { - Percentage of foreign } \\
\text { ownership (> 5\%) } \\
\text { - Dummy, } 1 \text { if the CEO has } \\
\text { experience working abroad } \\
\text { least one year or the CEO is } \\
\text { from abroad, } 0 \text { otherwise } \\
\text { - Dummy, } 1 \text { if the Islamic bank is } \\
\text { the parent/subsidiary of Islamic } \\
\text { banks in other countries or is } \\
\text { affiliated with a bank in another } \\
\text { country, } 0 \text { otherwise }\end{array}$ \\
\hline \multicolumn{3}{|c|}{ Islamic Corporate Governance } \\
\hline - IG-Score & ICGS & $\begin{array}{l}\text { - Score accumulated values of } 6 \\
\text { characteristics of SSB. }\end{array}$ \\
\hline - Number of SSB & NSSB & - The number of members of SSB \\
\hline - Reputation of SSB & REPT & $\begin{array}{l}\text { - Dummy, } 1 \text { if there is one } \\
\text { member of the SSB which is } \\
\text { a member of the committee } \\
\text { or the supervisory board of } \\
\text { AAOIFI, } 0 \text { otherwise. }\end{array}$ \\
\hline - Cross Membership & CROS & $\begin{array}{l}\text { - Dummy, } 1 \text { if there is a member } \\
\text { of SSB who fills positions as } \\
\text { members of the SSB in other } \\
\text { banks. }\end{array}$ \\
\hline $\begin{array}{l}\text { - Educational } \\
\text { Background in } \\
\text { Economics \& Business }\end{array}$ & ECON & $\begin{array}{l}\text { - Dummy, } 1 \text { if at least one } \\
\text { member of SSB has an } \\
\text { academic background in } \\
\text { economics and business, } 0 \\
\text { otherwise. }\end{array}$ \\
\hline $\begin{array}{l}\text { - Educational } \\
\text { Background in Islamic } \\
\text { or Sharia Law }\end{array}$ & SHAR & $\begin{array}{l}\text { - Dummy, } 1 \text { if there is at least } \\
\text { one member of SSB who has an } \\
\text { academic background in law or } \\
\text { Islamic law, } 0 \text { otherwise. }\end{array}$ \\
\hline
\end{tabular}


- Doctoral Qualification DOCT •Dummy, 1 if at least one member of SSB has the educational background or equivalent doctoral.

\begin{tabular}{lll}
\hline \multicolumn{2}{l}{ Social and Political Context } & \\
\hline $\begin{array}{c}\text { • Political Rights and PRCL } \\
\text { Civil Liberties }\end{array}$ & $\begin{array}{l}\text { - Aggregate score value of } \\
\text { Political Rights and Civil } \\
\text { Liberties. Range of values 1 } \\
\text { (repression) to 100 (freedom). }\end{array}$ \\
\hline Control Variable & & \\
\hline - Age Company & AGE & $\begin{array}{l}\text { - Numbers of years of operation } \\
\text { since the establishment }\end{array}$ \\
- Company size & SIZE & $\begin{array}{l}\text { - Log total assets } \\
\text { - Return on Equity }\end{array}$ \\
\hline
\end{tabular}

In this study, to examine the influence of internationality factor and Islamic Corporate Governance and the socio-political context of the state on

the level of Islamic bank ISR disclosure, the researcher conducted hypothesis testing using two research models. The first model is to use IG-Score which is the cumulative value of 6 SSB characteristics, while the second model uses a dummy variable for each SSB characteristic. The second model is an additional analysis to find out more whether each SSB attribute affects the ISR disclosure level. Here is the first model using IG-Score:

$$
\begin{gathered}
\text { DISC }_{i t}=\beta_{0}+\beta_{1} \text { FOREIGN }_{i t}+\beta_{2} \text { EXP }_{i t}+\beta_{3} \text { MULTI }_{i t}+\beta_{4} I C G S_{i t}+\beta_{5} P R C L_{i t} \\
+\beta_{6} A G E_{i t}+\beta_{6} \text { SIZE }_{i t}+\beta_{7} R O E_{i t}+e
\end{gathered}
$$

The second analysis model uses dummy variables for each SSB characteristic. This model is an additional analysis to find out more whether each SSB attribute affects the ISR disclosure level. Here is a second model that uses dummy variables:

$$
\begin{aligned}
\text { DISC }_{i t}=\beta_{0}+ & \beta_{1} \text { FOREIGN }_{i t}+\beta_{2} \text { EXP }_{i t}+\beta_{3} \text { MULTI }_{i t}+\beta_{4} N_{S S B_{i t}}+\beta_{5} R E P T_{i t} \\
& +\beta_{6} \text { CROSS }_{i t}+\beta_{7} \text { ECON }_{i t}+\beta_{8} \text { SHAR }_{i t}+\beta_{9} D_{\text {DOCT }} i t \\
& +\beta_{10} \text { PRCL }_{i t} \text { AGE }_{i t}+\beta_{12} \text { SIZE }_{i t}+\beta_{13} \text { ROE }_{i t}+e
\end{aligned}
$$

\section{RESULTS AND DISCUSSION}

\section{Cross-country ISR Disclosure Analysis}

Table 4 shows the average ISR disclosure in different countries in 2014-2016. We found some interesting findings from the content analysis of the Islamic bank's annual report. Countries with highest ISR disclosure rates are Pakistan and UAE (55\%). While the country with the lowest disclosure rate is Turkey (27\%). There are more dominant countries expressing ISRs in certain dimensions, but there are also countries that do not reveal at all. However, the overall level of ISR disclosure is still 
low (44.16\%). Our findings are consistent with El-Halaby \& Hussainey (2015) and Farook et al. (2011).

Indonesia with an average of 45 percent more dominant disclosure revealed information related to SSB (97\%) and zakah (80\%), but less attention to disclosure related to environmental preservation policy $(10 \%)$. The Kingdom of Saudi Arabia paid less attention to the disclosure of information related to the SSB report (22\%) and waqf management,

Journal of Islamic Economics, Finance, and Banking

Vol. 4, No. 1, June 2021, pp. 59-79, ISSN p:2622-4755 e:2622-4798 but more dominantly revealed information related to zakah (100\%) and customer service (70\%). The UAE is very concerned about disclosures related to client compliance screening based on the principles of sharia $(100 \%)$ and zakah (100\%), but lacks disclosure in terms of management of waqf and Qard Hassan funds (27\%). Among other countries, Turkey pays very less attention to the disclosure of ISR. The Islamic Bank in Turkey does not make a special section in its annual report containing the SSB report, there is no disclosure of how the company handles nonconformity with sharia, no information of Qard Hassan's fund no zakah.

Table 4. Level of ISR Disclosure of Countries

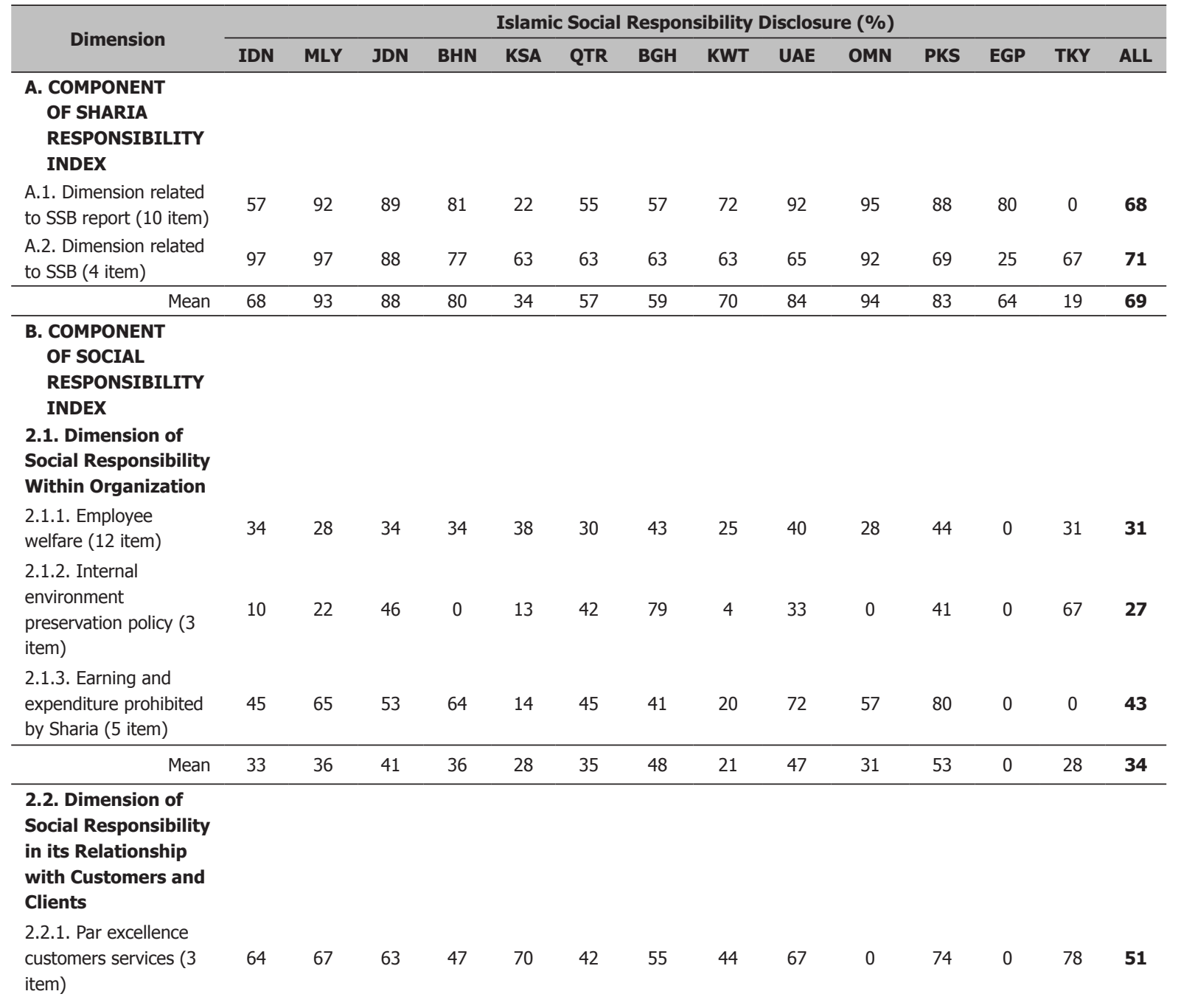




\section{IHTIFAZ - JIEFB}

\begin{tabular}{|c|c|c|c|c|c|c|c|c|c|c|c|c|c|c|}
\hline $\begin{array}{l}\text { and Avoiding Onerous } \\
\text { Contractual Terms ( } 9 \\
\text { item) }\end{array}$ & 27 & 22 & 42 & 45 & 10 & 30 & 24 & 11 & 49 & 26 & 43 & 56 & 0 & 30 \\
\hline $\begin{array}{l}\text { 2.2.3. Qard Hassan (6 } \\
\text { item) }\end{array}$ & 53 & 9 & 44 & 16 & 13 & 0 & 29 & 36 & 27 & 14 & 26 & 0 & 0 & 20 \\
\hline $\begin{array}{l}\text { 2.2.4. Special Fitures } \\
\text { (6 item) }\end{array}$ & 55 & 68 & 50 & 50 & 63 & 53 & 81 & 40 & 70 & 50 & 63 & 33 & 67 & 57 \\
\hline Mean & 45 & 36 & 47 & 39 & 32 & 30 & 43 & 29 & 51 & 26 & 48 & 29 & 26 & 37 \\
\hline \multicolumn{15}{|l|}{$\begin{array}{l}\text { 2.3. Dimension of } \\
\text { Social Responsibility } \\
\text { in Screening } \\
\text { Investment }\end{array}$} \\
\hline $\begin{array}{l}\text { 2.3.1. Screening of } \\
\text { Clients for Compliance } \\
\text { with Islamic } \\
\text { Principles and Social } \\
\text { Responsibility ( } 2 \text { item) }\end{array}$ & 54 & 30 & 50 & 50 & 20 & 63 & 50 & 30 & 100 & 100 & 100 & 50 & 33 & 56 \\
\hline \multicolumn{15}{|l|}{$\begin{array}{l}\text { 2.3.2. Investment } \\
\text { Quotas Based on } \\
\text { Industry, Social } \\
\text { Impact, and } \\
\text { Environmental Impact } \\
\text { (5 item) }\end{array}$} \\
\hline Mean & 38 & 24 & 38 & 27 & 30 & 35 & 48 & 29 & 51 & 43 & 48 & 29 & 38 & 37 \\
\hline \multicolumn{15}{|l|}{$\begin{array}{l}\text { 2.4. Social } \\
\text { Responsibility to } \\
\text { Society }\end{array}$} \\
\hline 2.4.1. Zakah (1 item) & 80 & 100 & 100 & 100 & 100 & 100 & 79 & 93 & 100 & 100 & 89 & 100 & 0 & 88 \\
\hline $\begin{array}{l}\text { 2.4.2. Charitable } \\
\text { activates ( } 4 \text { item) }\end{array}$ & 46 & 53 & 75 & 42 & 45 & 29 & 39 & 42 & 35 & 50 & 44 & 75 & 50 & 48 \\
\hline $\begin{array}{l}\text { 2.4.3. Waqf } \\
\text { management ( } 2 \text { item) }\end{array}$ & 14 & 40 & 0 & 30 & 0 & 0 & 64 & 0 & 0 & 0 & 17 & 50 & 0 & 17 \\
\hline Mean & 42 & 56 & 57 & 47 & 40 & 31 & 52 & 37 & 34 & 43 & 43 & 71 & 29 & 45 \\
\hline $\begin{array}{c}\text { Total of Average ISR } \\
\text { Disclosure }\end{array}$ & 45 & 48 & 53 & 46 & 32 & 37 & 49 & 35 & 55 & 44 & 55 & 32 & 27 & 44 \\
\hline
\end{tabular}

\section{Descriptive Statistics}

Table 5 shows the results of descriptive statistical analysis of variables. From all observations on the disclosure level of ISR (DISC), the average level of ISR disclosure across the country is still very low at $44 \%$. This shows that Islamic banks in various countries still have not paid attention to the disclosure of the value of sharia and its social value in the company's annual report. A considerable distance between the minimal value $(18 \%)$ and the maximum (68\%) indicates a very variable level of ISR disclosure across countries. Compared with previous 
research, the Islamic bank ISR disclosure value that we found was not much different from previous research that is El-Halaby \& Hussainey (2015) with an average of $26 \%$ level of disclosure, and Farook et al. (2011) with an average of $17 \%$ level of disclosure.

Table 5. Descriptive Statistics

\begin{tabular}{llrrrr}
\hline Variable & N & \multicolumn{1}{c}{ MIN } & \multicolumn{1}{c}{ MAX } & \multicolumn{1}{c}{ MEAN } & \multicolumn{1}{c}{ STD.DEV } \\
\hline DISC & 148 & 18.06 & 68.06 & 44.16 & 11.28 \\
FOREIGN & 148 & 0.00 & 0.99 & 0.17 & 0.29 \\
EXP & 148 & 0.00 & 1.00 & 0.45 & 0.50 \\
MULTI & 148 & 0.00 & 1.00 & 0.24 & 0.43 \\
NSSB & 148 & 1.00 & 12.00 & 4.03 & 2.11 \\
REPT & 148 & 0.00 & 1.00 & 0.38 & 0.49 \\
CROS & 148 & 0.00 & 1.00 & 0.86 & 0.35 \\
ECON & 148 & 0.00 & 1.00 & 0.34 & 0.47 \\
SHAR & 148 & 0.00 & 1.00 & 0.98 & 0.14 \\
DOCT & 148 & 0.00 & 1.00 & 0.92 & 0.27 \\
ICGS & 148 & 2.00 & 6.00 & 4.29 & 0.96 \\
PRCL & 148 & 10.00 & 65.00 & 39.70 & 18.17 \\
AGE & 148 & 0.50 & 45.00 & 16.48 & 11.92 \\
SIZE & 148 & 54.580 & 90.589 .823 & 8.503 .229 & 13.894 .591 \\
ROE & 148 & -0.49 & 0.32 & 0.08 & 0.10 \\
\hline
\end{tabular}

Vol. 4, No. 1, June 2021, pp. 59-79, ISSN p:2622-4755 e:2622-4798

We found an interesting finding regarding the number of SSB (NSSB) in Islamic banks in various countries. The average Islamic bank has 4 members of SSB, but the gap between the minimum and maximum value is very much different which is 1 person and 12 people. We found that Islamic banks with many SSBs are Islamic banks from Bangladesh. The average value of corporate governance of Islamic banks in various countries shows good value (4.29), we found almost all Islamic banks have SSB qualified doctoral education. In addition, if we observe the size of Islamic banks (SIZE) assets in various countries vary widely with the lowest value of USD 54.580 million and the highest value of USD 90.589.823 million (Al Rajhi Bank). The majority of Islamic banks with large assets are Islamic banks from KSA, Kuwait and Qatar.

\section{Regression Analysis}

This study aims to examine the factors that affect the disclosure of ISR Islamic banks in various countries. This study focuses on testing factors related to internationalities, Islamic corporate governance of the SSB, and socio-political context in which Islamic banks originate. Table 6 shows the results of statistical tests of Ordinary Least Square (OLS) regression using the software Stata version 14. Based on the model specification test showed $F$-value 11.79 and significantly below 1 percent level, this indicates the overall model is good. In addition, 
the $R^{2}$ value of this model shows the value of 0.4042 which means that the overall independent variable can explain $40 \%$ of the total variation of ISR disclosure.

Table 6. Regression Analysis Model 1

\begin{tabular}{|c|c|c|c|c|}
\hline $\begin{array}{r}\overline{D I S C}_{i t}=\beta_{0}+\beta_{1} F O P \\
+\beta_{6} S t\end{array}$ & $\begin{array}{l}G_{i t}+\beta_{2} E X P \\
i_{i t}+\beta_{7} R O E_{i t}+\end{array}$ & $\beta_{3} M{ }^{\prime} L T I_{i t}+\beta_{4} I C$ & $S_{i t}+\beta_{5} P R C L$ & ${ }_{i t}+\beta_{6} A G E_{i t}$ \\
\hline Variable & $\begin{array}{l}\text { Predicted } \\
\text { Sign }\end{array}$ & Coefficients & t-statistic & p-value \\
\hline Cons & & 13.22474 & 1.27 & 0.207 \\
\hline FOREIGN & + & 6.89370 & 2.57 & $0.011^{* *}$ \\
\hline EXP & + & 0.21861 & 0.12 & 0.908 \\
\hline MULTI & + & 5.66773 & 2.73 & $0.007^{* * *}$ \\
\hline ICGS & + & 6.71119 & 6.25 & $0.000^{* * *}$ \\
\hline PRCL & + & 0.33202 & 6.11 & $0.000^{* * *}$ \\
\hline AGE & + & 0.09588 & 1.37 & 0.173 \\
\hline SIZE & + & -1.21830 & -1.75 & $0.083 *$ \\
\hline ROE & + & 36.94386 & 3.64 & $0.000^{* * *}$ \\
\hline Number of Obs. & & 148 & & \\
\hline F-value & & 11.79 & & \\
\hline Sig.F ( $p$-value) & & 0.0000 & & \\
\hline R-squared & & 0.4042 & & \\
\hline Adj. R-squared & & 0.3699 & & \\
\hline
\end{tabular}

Notes: $*, * *, * * *$ Represent significance at $0.10,0.05$ and 0.01 levels respectively

Based on Table 6, the test results indicate that variables that are shown to affect ISR disclosure rates are foreign share ownership (FOREIGN), multinational Islamic bank status (MULTI), Islamic corporate governance of SSB (ICGS) and socio-political conditions (PRCL). Based on the test results, $\mathrm{H} 1 \mathrm{a}$ and $\mathrm{H} 1 \mathrm{c}$ are accepted, but reject $\mathrm{H} 1 \mathrm{~b}$. From the proven internationality aspect in this research is the factor of the number of foreign ownership and the status of the multinational Islamic bank. In contrast to Slater and Dixon-Fowler (2009), this study found no influence of the CEO's experience on disclosure levels. This may be due to the lack of flexibility of Islamic banks to appoint CEOs from outside the country, as it prioritizes CEOs who understand the characteristics of Islamic finance.

The study found that Islamic corporate governance of SSB (ICGS) significantly affects the ISR disclosure rate and therefore we accept H2. A higher SSB qualification may increase the ISR's disclosure of companies that show more effective oversight of Islamic banks when they have highly qualified SSBs. This study is in line with the results of Farook et al. (2011) who found that IG-Score can improve corporate social responsibility disclosure. 
The study found that the socio-political context of the state (PRCL) significantly affects the disclosure rate of the ISR, therefore H3 is accepted. The freer socio-political conditions, the supervision of social institutions and society towards an entity becomes higher. Thus, Islamic banks are encouraged to disclose their sharia and social responsibility as legitimacy and to meet the expectations of stakeholders. The results of this study are in line with stakeholder theory (Clarkson, 1995) and consistent as found by Farook et al. (2011).

Table 7. Regression Analysis Model 2

\begin{tabular}{|c|c|c|c|c|}
\hline Variable & Predicted Sign & Coefficients & t-statistic & p-value \\
\hline Cons & & 19.42185 & 1.65 & 0.102 \\
\hline FOREIGN & + & 6.52683 & 2.39 & $0.018^{* *}$ \\
\hline EXP & + & 0.44606 & 0.23 & 0.818 \\
\hline MULTI & + & 7.21842 & 3.34 & $0.001^{* * *}$ \\
\hline NSSB & + & 1.62854 & 3.12 & $0.002^{* * *}$ \\
\hline REPT & + & 8.39677 & 3.94 & $0.000^{* * *}$ \\
\hline CROSS & + & 6.08410 & 2.58 & $0.011^{* *}$ \\
\hline ECON & + & 7.68664 & 4.31 & $0.000^{* * *}$ \\
\hline SHAR & + & 0.49157 & 0.14 & 0.889 \\
\hline DOCT & + & 1.68109 & 0.60 & 0.553 \\
\hline PRCL & + & 0.28183 & 4.50 & $0.000^{* * *}$ \\
\hline AGE & + & 0.07485 & 1.02 & 0.311 \\
\hline SIZE & + & -0.82690 & -1.16 & 0.250 \\
\hline ROE & + & 26.76698 & 2.57 & $0.011^{* *}$ \\
\hline \multicolumn{2}{|c|}{ Number of Obs. } & 148 & & \\
\hline \multicolumn{2}{|l|}{ F-value } & 8.28 & & \\
\hline \multicolumn{2}{|c|}{ Sig.F (p-value) } & 0.0000 & & \\
\hline \multicolumn{2}{|l|}{ R-squared } & 0.4456 & & \\
\hline \multicolumn{2}{|c|}{ Adj. R-squared } & 0.3918 & & \\
\hline
\end{tabular}

Notes: $*, * *, * * *$ Represent significance at $0.10,0.05$ and 0.01 levels respectively

In Model 1, ICGS is proxied in index form, so we try to analyze more deeply whether the factors in this ICGS overall affect the level of ISR disclosure or only partially. Table 7 shows the test results using the SSB characteristics separately. Compared to the previous model, $R^{2}$ in this model is larger (0.4456). This suggests that this model could explain further the variation in the level of Islamic banking ISR disclosure.

Based on Table 7, it can be seen that those who influence ISR disclosure are the proportion of foreign share ownership (FOREIGN), the characteristics of multinational Islamic banks (MULTI), socio-political conditions $(P R C L)$, and SSB characteristics related to the number of 
SSB (NSSB), reputation (REPT), cross membership (CROSS), and the existence of SSB qualified in economic and business (ECON). These IHTIFAZ - JIEFB

results corroborate previous studies that received $\mathrm{H} 1 \mathrm{a}, \mathrm{H} 1 \mathrm{C}, \mathrm{H} 2$, and H3. Furthermore, the second model explains again that not all SSB characteristics affect the level of disclosure. Test results show that the presence of SSB qualified sharia and doctoral education does not affect the level of ISR disclosure. In our opinion, the factor of sharia education qualification does not affect the level of disclosure of ISR because basically disclosure of information in the annual report of the company does not become a concern of expertise in the sharia field. This result is in accordance with El-Halaby \& Hussainey (2016) study that found the effect of SSB cross-membership, reputation, and SSB on level of ISR disclosure.

\section{CONCLUSION}

This paper aims to examine the determinants of ISR disclosure by Islamic Bank in various countries. We content-analyse an annual report from 52 Islamic banks from 13 countries, we examine three main aspects of the bank which is internationality, Islamic corporate governance of the Sharia Supervisory Board, and the Socio-Political context of the country. We measure Islamic bank ISRs based on minimum standards of disclosure under AAOIFI.

We find that ISR disclosures in various countries vary widely. However, overall ISR disclosure throughout the country is still very low at around 44 percent of total disclosure items. From the internationality aspect, we found that the proportion of foreign ownership shares and the status of the multinational Islamic banks influenced the level of disclosure, but we did not find that the CEO's overseas experience affected the level of disclosure. From the Islamic corporate governance aspect of Islamic banks, we found that the characteristic of ICG from SSB has a positive effect on ISR disclosure level. From the additional analysis we found that SSB characteristics related to the number of SSB members, reputation, the presence of SSB members qualified business economic education and cross membership of SSB positively affected the ISR disclosure level. In addition, we found that the socio-political conditions of the Islamic bank's origin state strongly influence the level of disclosure. Islamic banks originating from repressive countries tend to less disclose information on ISR, on the other hand Islamic banks originating from countries with free socio-political conditions tend to have higher levels of ISR disclosure.

\section{ACKNOWLEDGEMENTS}

We would like to thank all anonymous reviewers for their helpful comments. Maulana Acknowledge financial support from Indonesia Endowment Fund for Education (LPDP Indonesia) and Universitas Pembangunan Nasional Veteran Jakarta. 


\section{REFERENCES}

AAOIFI. (2015a). Corporate Social Responsibility Conduct and Disclosure for Islamic Financial Institutions (Governance Standard No. 7). Accounting and Auditing Organization for Islamic Financial Institutions.

AAOIFI. (2015b). Sharia Supervisory Board: Appointment, Compositions and Report (Governance Standard No. 1). Accounting and Auditing Organization for Islamic Financial Institutions.

Abu-Tapanjeh, A. M. (2009). Corporate governance from the Islamic perspective: A comparative analysis with OECD principles. Critical Perspectives on Accounting, 20(5), 556-567.

Akhtaruddin, M., Hossain, M., Hossain, M., \& Yao, L. (2009). Corporate governance and voluntary disclosure in corporate annual reports of Malaysian listed firms. Journal of Applied Management Accounting Research, 7(1).

Branco, M. C., \& Rodrigues, L. L. (2008). Factors Influencing Social Responsibility Disclosure by Portuguese Companies. Journal of Business Ethics, 83(4), 685-701. https://doi.org/10.1007/s10551007-9658-z

Choi, J.-S. (1999). An investigation of the initial voluntary environmental disclosures made in Korean semi-annual financial reports. Pacific Accounting Review, 11(1).

Clarkson, M. E. (1995). A stakeholder framework for analyzing and evaluating corporate social performance. Academy of Management Review, 20(1), 92-117.

Dahya, J., Lonie, A. A., \& Power, D. M. (1996). The case for separating the roles of chairman and CEO: An analysis of stock market and accounting data. Corporate Governance: An International Review, $4(2), 71-77$.

Deegan, C. (2002). Introduction: The legitimising effect of social and environmental disclosures - a theoretical foundation. Accounting, Auditing \& Accountability Journal, 15(3), 282-311. https://doi. org/10.1108/09513570210435852

El-Halaby, S., \& Hussainey, K. (2015). The determinants of social accountability disclosure: Evidence from islamic banks around the world. International Journal of Business, 20(3), 202-223.

El-Halaby, S., \& Hussainey, K. (2016). Determinants of compliance with AAOIFI standards by Islamic banks. International Journal of Islamic and Middle Eastern Finance and Management, 9(1), 143-168. https://doi.org/10.1108/IMEFM-06-2015-0074

Ernst and Young. (2016). World Islamic Banking Competitiveness Report 2016. In Ernst and Young.

Fama, E. F., \& Jensen, M. C. (1983). Separation of ownership and control. The Journal of Law and Economics, 26(2), 301-325.

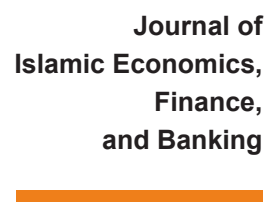

Vol. 4, No. 1, June 2021 , pp. 59-79, ISSN p:2622-4755 e:2622-4798 
Farook, S., Kabir Hassan, M., \& Lanis, R. (2011). Determinants of corporate social responsibility disclosure: the case of Islamic banks. Journal of Islamic Accounting and Business Research, 2(2), 114-141. https://doi.org/10.1108/17590811111170539

Fifka, M. S., \& Pobizhan, M. (2014). An institutional approach to corporate social responsibility in Russia. Journal of Cleaner Production, 82, 192-201.

Freedom House / Expanding freedom and democracy. (n.d.).

Freeman, R. E. (1994). The politics of stakeholder theory: Some future directions. Business Ethics Quarterly, 409-421.

Freeman, R. E., Wicks, A. C., \& Parmar, B. (2004). Stakeholder Theory and "The Corporate Objective Revisited." Organization Science, 15(3), 364-369. https://doi.org/10.1287/orsc.1040.0066

Garas, S. N., \& Pierce, C. (2010). Shari'a supervision of Islamic financial institutions. Journal of Financial Regulation and Compliance, 18(4), 386-407.

Guthrie, J., \& Parker, L. D. (1989). Corporate Social Reporting: A Rebuttal of Legitimacy Theory. Accounting and Business Research, 19(76), 343-352. https://doi.org/10.1080/00014788.1989.9728863

Hahn, R., \& Kühnen, M. (2013). Determinants of sustainability reporting: a review of results, trends, theory, and opportunities in an expanding field of research. Journal of Cleaner Production, 59, 5-21. https:// doi.org/10.1016/j.jclepro.2013.07.005

Hamdi, F. M., \& Zarai, M. A. (2012). Earnings Management to Avoid Earnings Decreases and Losses: Empirical Evidence from Islamic Banking Industry. Research Journal of Finance and Accounting, 3(3), 88-107.

Haniffa, R. M. (2001). Social responsibility disclosure: An Islamic perspective. Department of Accounting and Finance, University of Exeter, 1(4).

Haniffa, R. M., \& Cooke, T. E. (2002). Culture, corporate governance and disclosure in Malaysian corporations. Abacus, 38(3), 317-349.

IFSB. (2016). Islamic Financial Services Industry Stability Report 2016.

Khurshid, M. A., Al-Aali, A., Soliman, A. A., \& Amin, S. M. (2014). Developing an Islamic corporate social responsibility model (ICSR). Competitiveness Review, 24(4), 258-274. https://doi.org/10.1108/ CR-01-2013-0004

Maali, B., Casson, P., \& Napier, C. (2006). Social reporting by islamic banks. Abacus, 42(2), 266-289. https://doi.org/10.1111/j.1467$6281.2006 .00200 . x$

Mersni, H., \& Ben Othman, H. (2016). The impact of corporate governance mechanisms on earnings management in Islamic banks in the Middle East region. Journal of Islamic Accounting and Business Research, 
Mitchell Williams, S. (1999). Voluntary environmental and social accounting disclosure practices in the Asia-Pacific region: An international empirical test of political economy theory. International Journal of Accounting, 34(2).

Muneeza, A., Ma'ruf, A., \& Alam, S. (2020). CSR Contribution to SocioEconomic Development: Evidence from Indonesian Islamic Banks. Ihtifaz: Journal of Islamic Economics, Finance, and Banking, 3(1), 13-26. https://doi.org/10.12928/ijiefb.v3i1.949

Nahar, F. H., Faza, C., \& Azizurrohman, M. (2020). Macroeconomic Analysis and Financial Ratios on Sharia Commercial Bank Profitability: A Case Study of Indonesia. Ihtifaz: Journal of Islamic Economics, Finance, and Banking, 3(1), 37-49. https://doi.org/10.12928/ijiefb.v3i1.1721

Riduwan, Mutmainah, L., \& Wahyudi, R. (2020). Islamic Social Reporting Disclosure of Sharia Commercial Banks in Indonesia: A Form of Social Responsibility. Shirkah - Journal of Economics and Business, 5(3), 337-361.

Sellami, Y. M., \& Tahari, M. (2017). Factors influencing compliance level with AAOIFI Financial accounting standards by Islamic banks. Journal of Applied Accounting Research, 18(1), 137-159. https://doi. org/10.1108/JAAR-01-2015-0005

Singh, M., Mathur, I., \& Gleason, K. C. (2004). Governance and Performance Implications of Diversification Strategies: Evidence from Large U.S. Firms. The Financial Review, 39(4), 489-526. https://doi. org/10.1111/j.0732-8516.2004.00086.x

Slater, D. J., Dixon-fowler, H. R., Slater, B. D., \& Dixon-fowler, H. R. (2009). CEO International Assignment Experience and Corporate Social Performance. Journal of Business Ethics, 89(3), 473-489. https:// doi.org/10.1007/sl0551-008-0011-y

Srairi, S. (2019). Transparency and bank risk-taking in GCC Islamic banking. Borsa Istanbul Review, 19, S64-S74. https://doi.org/10.1016/j. bir.2019.02.001

Thompson, K. W., \& Gastil, R. D. (1982). Freedom in the World: Political Rights and Civil Liberties, 1981. Human Rights Quarterly, 4(4), 538. https://doi.org/10.2307/762216

Vinnicombe, T. (2010). AAOIFI reporting standards: Measuring compliance. Advances in Accounting, 26(1), 55-65. https://doi. org/10.1016/j.adiac.2010.02.009

Wibowo, M. G. (2020). Good Public Governance in Islamic Perspective: An Analysis on the World Governance Indicator in OIC Member Countries. Ihtifaz: Journal of Islamic Economics, Finance, and Banking, 3(1), 51-65. https://doi.org/10.12928/ijiefb.v3i1.1718 